\title{
Biochemical systematics and evolutionary relationships in the Trichoniscus pusillus complex (Crustacea, Isopoda, Oniscidea)
}

\author{
MARINA COBOLLI SBORDONI $\dagger$, VALERIO KETMAIER $\ddagger *$, ELVIRA DE MATTHAEIS $\ddagger \&$ \\ STEFANO TAITI§ \\ $\dagger$ †ipartimento di Scienze Ambientali, Università di L'Aquila, V.Vetoio, Località Coppito-67010-L'Aquila, \\ $\ddagger$ Dipartimento di Biologia Animale e dell'Uomo, Università di Roma 'La Sapienza', V.le dell'Università 32- \\ 00185-Rome and \$Centro di Studio per la Faunistica ed Ecologia Tropicali CNR, V.Romana 17-50125- Florence, Italy
}

In order to clarify taxonomic and phylogenetic relationships among Trichoniscus pusillus (Isopoda, Oniscidea) populations, allozyme variation was studied by means of starch gel electrophoresis. The genetic structure of several populations belonging to different subspecies (diploid bisexual, triploid parthenogenetic; epigean, troglophilic and troglobitic) was assessed by investigating 10 enzymatic systems corresponding to 15 putative loci. $F$-statistics and clustering analysis indicated a high degree of genetic differentiation, corresponding to low levels of gene flow among populations, both epigean and hypogean, still considered to be conspecific. Estimates of divergence times calculated from genetic distance data suggest that the pattern of differentiation and the colonization of cave environments may be related to the palaeoclimatic change of the Messinian and Plio-Pleistocene glaciations.

Keywords: allozymes, cave fauna, divergence times, genetic polymorphism, phylogeny, Trichoniscus pusillus.

\section{Introduction}

Trichoniscus pusillus Brandt, 1833 (Isopoda, Oniscidea) is considered to be a polytypic species, widely distributed in the Palaearctic region, whose populations have been arranged in several subspecies. These subspecies may occur at or above the soil surface (epigean), in caves and subterranean passages but not strictly confined to them (troglophilic), or only in caves (obligate cavernicolous, troglobitic). Moreover, they differ reproductively (diploid bisexual vs. triploid parthenogenetic) and show a strong homogeneity for the morphological characters traditionally used in the systematics of this group. On the other hand, they exhibit some variability in adaptive characters related to the colonization of subterranean environments (loss of the eye, body depigmentation, etc.).

The use of conventional subspecies is much debated, even though they are widely employed in the study of geographical variation caused by ecological patterns and/or historical processes. Böhme (1978) has pointed out that the subspecies concept, as defined by Mayr (1975) and generally

\footnotetext{
${ }^{*}$ Correspondence. E-mail: ketmaier@axrma.uniroma1.it
}

accepted, is arbitrary and subjective. Thorpe (1987) stressed that most species in natural circumstances may have patterns of geographical variation. As conventional subspecies are not natural categories, their use consequently forces noncategorical variation into categorical classes. Several approaches have been proposed to obtain a more realistic definition of subspecies (Böhme, 1978; Thorpe, 1987), all based on careful descriptions of morphological, ecological and interfertility parameters. On the other hand, many systematists continue to accept conventional infraspecific categories as a useful tool for describing patterns of variation, especially in animals with limited dispersal power and discontinuous distributions. This allows recognition of more or less differentiated populations without demonstrable sexual isolation, especially when the phenotypic differences are less than the average between recognized species in the same genus.

Analysis of the amount of genetic divergence between populations considered to belong to different subspecies should be a way of elucidating patterns of variation and differentiation. The present paper deals with the genetic structure of several natural populations belonging to different subspecies 
of Trichoniscus pusillus. In addition, a population of Trichoniscus matulicii Verhoeff, 1901, has been assayed to assess levels of genetic divergence among morphologically well-differentiated species in the genus Trichoniscus.

\section{Materials and methods}

\section{Study area and collecting sites}

Twelve populations (identified by three-letter codes) were analysed (collecting sites are indicated in Fig. 1). One population was obtained from Ulbach near Stuttgart (Germany, PUS) and belongs to the nominal subspecies Trichoniscus pusillus pusillus, widespread in central and northern Europe. This is a triploid form $(3 n=24)$ characterized by an obligate apomictic parthenogenesis (Vandel, 1960). Five are epigean populations, both continental (Sant'Ellero, near Florence, ELL) and insular (Francardo, Corsica, FRA; Tuscan Archipelago: Capraia Is.,

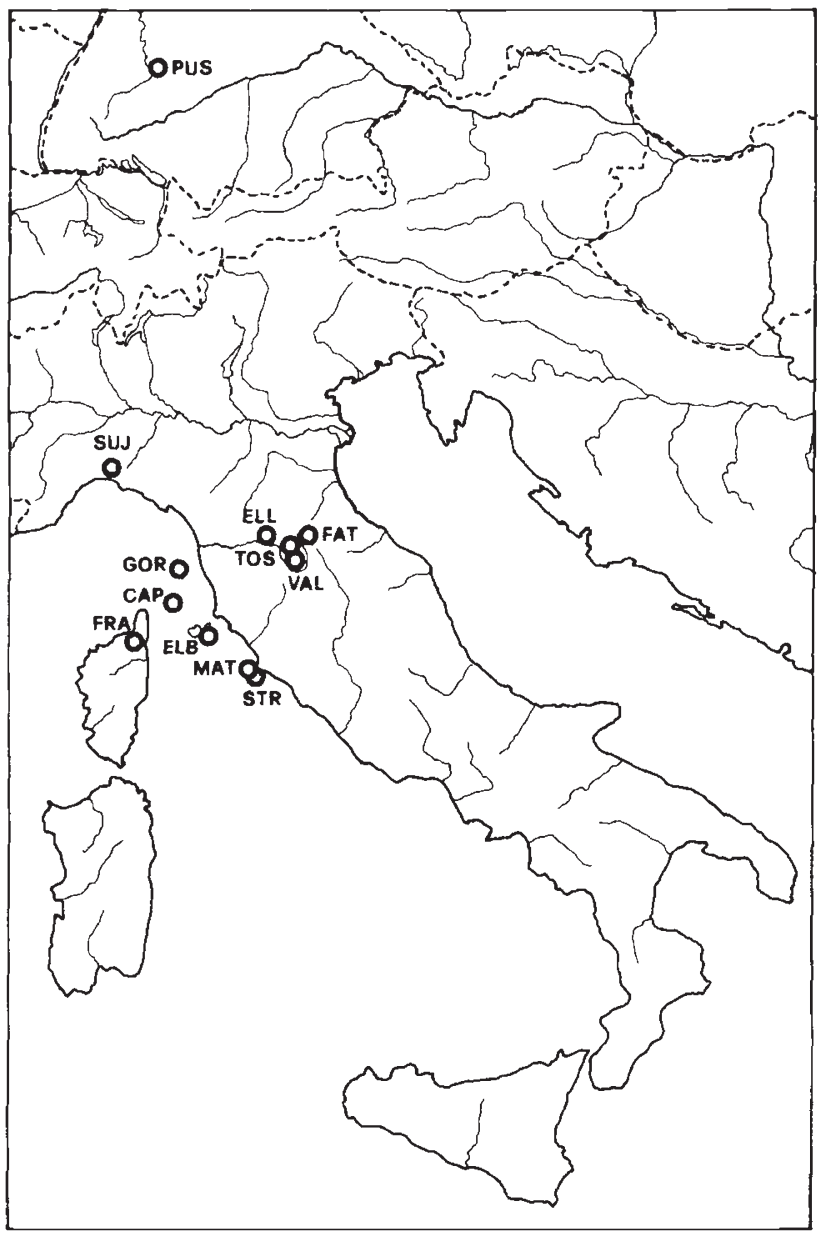

Fig. 1 Sampling localities of Trichoniscus populations. For the population symbols see text.
CAP; Elba Is., ELB; Gorgona Is., GOR), of Trichoniscus pusillus provisorius Racovitza, 1908, a taxon widely distributed in Europe, especially in the southern part, and the Mediterranean (Algeria, Lebanon). One population is of Trichoniscus pusillus baschierii Brian, 1953, a troglobitic form endemic to the Punta degli Stretti cave, Monte Argentario, Grosseto, Tuscany (STR). Three populations are of a new troglophilic taxon (Taiti \& Ferrara, 1995), belonging to the Trichoniscus pusillus complex, living in some natural caves of the Tuscan Apennines (Buca presso il Trogolin dell'Orso di Vallombrosa, Florence, VAL; Buca delle Fate di Tosi, Florence, TOS; Buca delle Fate di Badia Prataglia, Arezzo, FAT). A population of Trichoniscus pusillus sujensis Brian, 1926, is from the type locality, Grotta Suja, Monte Fasce, Genova, Liguria (SUJ). Finally, one population of Trichoniscus matulicii, a species with a trans-Adriatic distribution (Argano et al., 1978), comes from the Punta degli Stretti cave, Monte Argentario, Grosseto, Tuscany (MAT). All samples were transported alive to the laboratory and frozen at $-80^{\circ} \mathrm{C}$.

\section{Electrophoretic analysis}

Horizontal electrophoresis was performed on 12 per cent starch gels with crude homogenates in Tris- $\mathrm{HCl}$ 0.05 м pH 7.5 from each whole specimen. Ten enzymatic proteins were assayed for genetic variation: acid phosphatase (ACPH, EC 3.1.3.2), alkaline phosphatase (APH, EC 3.1.3.1), esterase (EST, EC 3.1.1.1), glucose-6-phosphate dehydrogenase (G6PD; EC 1.1.1.49), isocitrate dehydrogenase (IDH, EC 1.1.1.42), lactate dehydrogenase (LDH, EC 1.1.1.27), nonspecific dehydrogenase (NO-DH, EC 1.6.99.1), peptidase (PEP, EC 3.4.11.-), phosphoglucomutase (PGM, EC 5.4.2.2), phosphohexose isomerase (PHI, EC 5.3.1.9).These enzymes correspond to 15 putative loci. Buffers and electrophoretic conditions were according to De Matthaeis et al. (1983) and Cobolli Sbordoni et al. (1987).

The genetic relationships between diploid populations were estimated on the basis of genetic distance (D) values, calculated with Nei's method (1978) applied to the allele frequencies at the 15 common loci. To quantify the amount of genetic differentiation between the diploid populations and the triploid one, genetic similarity $(S)$ was calculated on the basis of genotype frequencies according to Hedrick's formula (1971), because it is usually impossible to decide which of two alleles is present in double dose in heterozygous triploids. Genetic relationships among all populations are represented by a dendro- 
gram plotted with the UPGMA clustering method (Sneath \& Sokal, 1973).

On the basis of the values of Rogers genetic distance (1972), with the method of outgroup rooting, a tree was drawn to estimate the phylogenetic relationships between populations by means of the distance Wagner procedure (DWP) (Farris, 1972).

The degree of genetic heterogeneity among all populations of $T$. pusillus was assessed using the $\Theta$ index (Weir \& Cockerham, 1984) as an estimator of $F_{\mathrm{ST}}$. An indirect estimate of gene flow is given by: $N m=\left(1 / F_{\text {ST }}-1\right) / 4$ (Wright, 1931), where $N$ is the effective population size and $m$ is the effective migration rate. Moreover, in order to obtain a detailed description of patterns of genetic heterogeneity and gene flow among Tuscan and Corsican populations, we arranged them in five groups on the basis of their geographical area: Apennine cave populations (VAL, TOS, FAT); Tuscan cave populations (STR, VAL, TOS, FAT); epigean-hypogean Tuscan populations (ELL, VAL, TOS, FAT, STR); insular epigean populations (FRA, CAP, GOR, ELB) and insular-continental epigean populations (ELL, FRA, CAP, GOR, ELB).

The genetic variability of samples was estimated by $H_{\mathrm{e}}$ (expected mean heterozygosity under HardyWeinberg equilibrium), $H_{\mathrm{o}}$ (observed mean heterozygosity), $P$ (proportion of polymorphic loci according to the criterion of the second most common allele being at least 1 per cent) and $A$ (mean number of alleles per locus). For the triploid parthenogenetic population (PUS), $H_{\mathrm{c}}$ was not calculated as the Hardy-Weinberg model is valid only for diploid bisexual organisms; however, an estimate of intrapopulation variability was obtained through Simpson's index (1949) (total clonal diversity, TCD). The Hardy-Weinberg model was checked by means of the fixation index $(F)$ and the null hypothesis $F=0$ was tested for significance with the $\chi^{2}$-test using the Levene (1949) correction. Correspondence analysis (Benzecri, 1973) was used to examine in detail allele frequency relationships among populations. All the data analysis was performed using programs BIOSYS-1 (no prior pooling of data) (Swofford \& Selander, 1981), FSTAT (Goudet, 1995) and the NTSYs package (Rohlf, 1988).

\section{Results}

The fifteen inferred loci were consistently scored. Just one locus $(\mathrm{No}-\mathrm{dh})$ was monomorphic in all study populations, whereas the remaining 14 (Acph-
1; Acph-2; Aph-1; Aph-2; Est-1; Est-2; Est-3; G6pd; Idh; Ldh; Pep-1; Pep-2; Pgm; Phi) were polymorphic at least in one population. In several cases alternative fixed alleles were found among populations. On the basis of genotype frequency data, the genetic similarity index $(S)$ (Hedrick, 1971) was calculated between all study populations (Table 1), and the genetic identity and distance indexes $(I ; D)$ (Nei, 1978) were employed to quantify genetic relationships among diploid populations (Table 1); the values obtained by the two methods gave patterns of differentiation of the same order of magnitude. $S$ varied from 0.848 (VAL vs. TOS) to 0.138 (MAT vs. ELB), whereas $I$ varied from 0.965 (VAL vs. TOS) to 0.159 (MAT vs. ELB). The dendrogram of Fig. 2, constructed from the $S$-values, synthesizes genetic relationships, showing the existence of different levels of genetic differentiation; the tree built according to the distance Wagner procedures (Farris, 1972), on the basis of Rogers genetic distance (1972), summarizes the evolutionary relationships (Fig. 3).

$\Theta$-values revealed a significant subdivision among all the populations of the $T$. pusillus complex (mean $\Theta=0.572$, mean $N m=0.226$, Table 2). Moreover, results from pairwise comparisons among Tuscan populations showed that, even for geographically close populations, $\mathrm{Nm}$-values were low, varying from 0.026 (STR vs. VAL) to 0.974 (VAL vs. TOS) (Table 3).

The correspondence analysis (Fig. 4) highlights the pattern of genetic divergence described by the UPGMA dendrogram: the MAT and SUJ populations are well differentiated; within the remaining populations axes I and II discriminate the cavernicolous from the epigean ones.

Genetic variability, expressed as observed heterozygosity $\left(H_{0}\right)$ ranged from 0.020 (ELB) to 0.237 (PUS) (Table 4). The genotype frequencies for the study populations were often not in Hardy-Weinberg equilibrium, with a lack of heterozygotes, as indicated by the high significance of $F$-values (Table $5)$. The total clonal diversity was calculated for PUS, giving an estimate of TCD $=5.263$ based on 10 different clones detected electrophoretically.

\section{Discussion}

In this study high levels of genetic differentiation were demonstrated among populations still considered to be conspecific. Indeed, according to Thorpe (1983), populations of dubious status with genetic identities below 0.85 probably represent 
separate species. The analysis of the distribution of $I$ and $S$ among our studied populations reveals that the $I$ - and $S$-values are near 0.8 in only three comparisons (VAL vs. TOS, VAL vs. FAT and FAT vs. TOS). Moreover, the high significance of $\Theta$-values strongly indicates that the overall genetic

Table 1 Above diagonal, genetic similarity $S$ (Hedrick, 1971) values for all Trichoniscus populations; below diagonal, genetic identity $I$ (upper) and genetic distance $D(\mathrm{Nei}, 1978)$ values (lower) for diploid populations

\begin{tabular}{lcccccccccccc}
\hline Population & MAT & STR & VAL & TOS & FAT & SUJ & PUS & ELL & FRA & CAP & ELB & GOR \\
\hline MAT & - & 0.256 & 0.266 & 0.268 & 0.264 & 0.262 & 0.197 & 0.228 & 0.234 & 0.222 & 0.138 & 0.149 \\
STR & 0.284 & - & 0.561 & 0.623 & 0.598 & 0.281 & 0.289 & 0.335 & 0.557 & 0.397 & 0.528 & 0.387 \\
& 1.260 & & & & & & & & & & & \\
VAL & 0.292 & 0.604 & - & 0.848 & 0.821 & 0.268 & 0.273 & 0.552 & 0.433 & 0.406 & 0.504 & 0.368 \\
& 1.230 & 0.504 & & & & & & & & & & \\
TOS & 0.302 & 0.668 & 0.965 & - & 0.798 & 0.267 & 0.312 & 0.693 & 0.547 & 0.440 & 0.547 & 0.410 \\
& 1.196 & 0.404 & 0.035 & & & & & & & & & \\
FAT & 0.290 & 0.648 & 0.868 & 0.870 & - & 0.343 & 0.273 & 0.486 & 0.498 & 0.345 & 0.426 & 0.361 \\
& 1.236 & 0.433 & 0.141 & 0.139 & & & & & & & & \\
SUJ & 0.278 & 0.308 & 0.292 & 0.304 & 0.336 & - & 0.449 & 0.373 & 0.236 & 0.171 & 0.323 & 0.260 \\
& 1.282 & 1.177 & 1.230 & 1.189 & 1.005 & & & & & & & \\
PUS & - & - & - & - & - & - & - & 0.629 & 0.260 & 0.266 & 0.403 & 0.354 \\
ELL & 0.275 & 0.462 & 0.571 & 0.646 & 0.576 & 0.443 & - & - & 0.451 & 0.437 & 0.600 & 0.490 \\
& 1.290 & 0.772 & 0.561 & 0.437 & 0.552 & 0.815 & & & & & & \\
FRA & 0.256 & 0.582 & 0.535 & 0.615 & 0.529 & 0.253 & - & 0.587 & - & 0.655 & 0.507 & 0.680 \\
& 1.362 & 0.542 & 0.625 & 0.486 & 0.637 & 1.374 & & 0.678 & & & & \\
CAP & 0.205 & 0.410 & 0.425 & 0.483 & 0.355 & 0.175 & - & 0.508 & 0.655 & - & 0.543 & 0.526 \\
& 1.587 & 0.891 & 0.856 & 0.729 & 1.035 & 1.745 & & 0.784 & 0.423 & & &
\end{tabular}

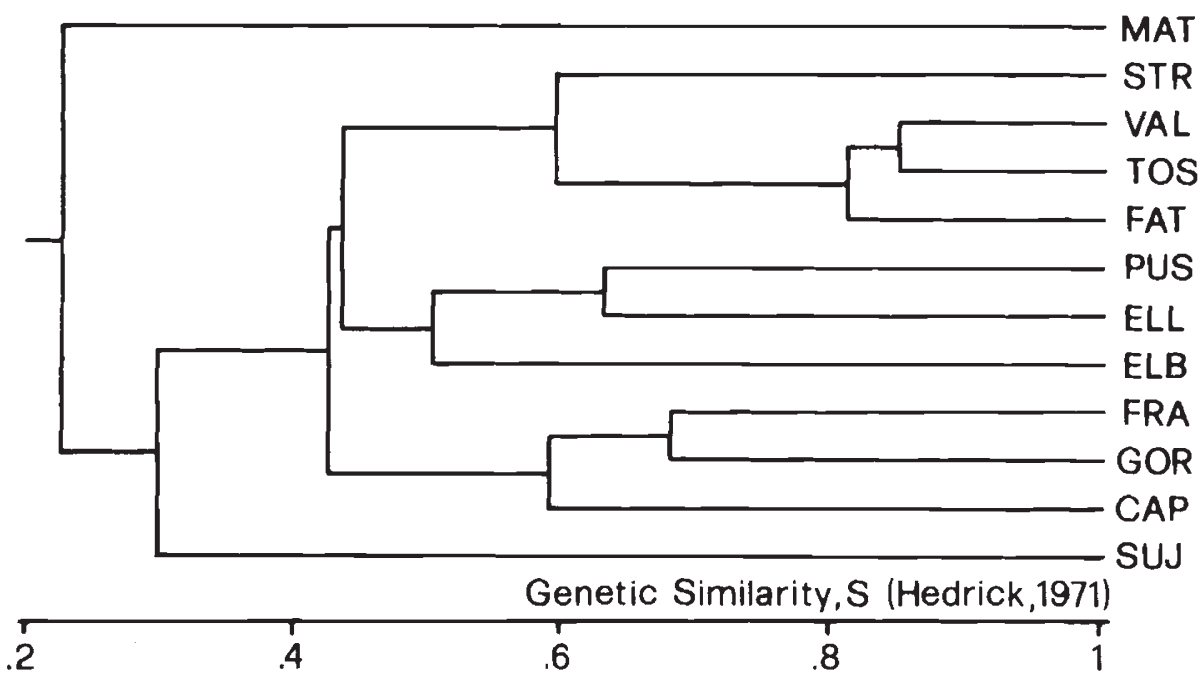

MAT

STR

VAL

TOS

FAT

PUS

ELB

FRA

GOR

SUJ Fig. 2 Dendrogram of Trichoniscus populations based on UPGMA clustering of the genetic similarity $(S)$ data reported in Table 2. 
Fig. 3 Dendrogram of presumed phylogenetic relationships of populations of Trichoniscus; distance Wagner procedure (Farris, 1972) on Rogers's genetic distance matrix. MAT is the outgroup.

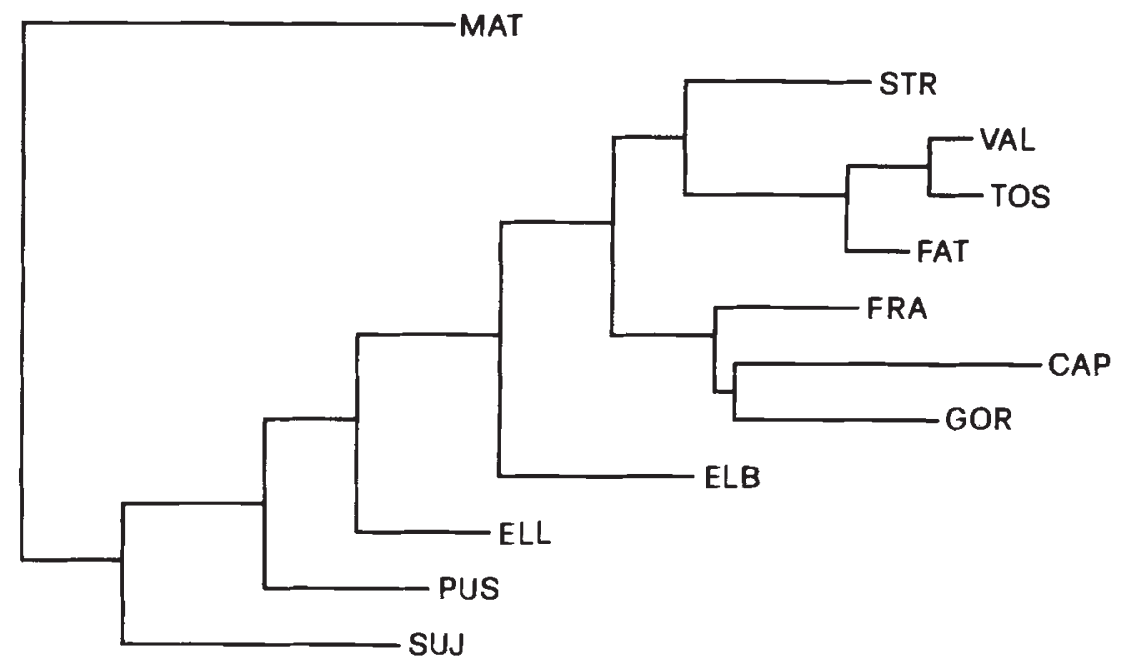

Distance from Root

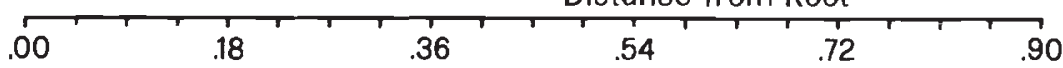

diversity is caused mostly by heterogeneity between populations. These high levels of genetic differentiation correspond to a substantial homogeneity (except for MAT) of the morphological characters traditionally used in the systematics of this group (mainly male pereiopode VII and pleopode I).

On account of its physiological features, the genus Trichoniscus can be considered preadapted to cave life, as documented by the existence of strictly troglobitic populations. Furthermore, most of the epigean populations are confined to litter and soil habitats which, in their ecological characteristics, may be partially comparable with a cave environment. Hence, the constancy of morphological taxonomic characters in genetically well-differentiated populations could result from analogous selective pressures (Jones et al., 1992). According to Culver (1982) many cavernicolous species, identified on a morphological basis, are species complexes and, to date, there is much experimental evidence of sibling species detected by biochemical markers (Laing et al., 1976; Cobolli Sbordoni et al., 1990).

Thus, the levels of genetic differentiation found in the studied populations allow us to confirm the

Table $2 \Theta$ and Nm values calculated over all loci for Trichoniscus pusillus populations

\begin{tabular}{lcccrrr}
\hline Locus & \multirow{2}{*}{ Number of alleles } & $\Theta$ & $\Theta J a c k k n i f i n g$ & \multicolumn{1}{c}{$\chi^{2}$} & d.f. & $N m_{\Theta}$ \\
\hline Acph -1 & 3 & 0.439 & 0.416 & 669.03 & 20 & 0.319 \\
Acph-2 & 5 & 0.963 & 0.975 & 2935.22 & 40 & 0.010 \\
Aph-1 & 4 & 0.419 & 0.400 & 889.95 & 30 & 0.346 \\
Aph-2 & 4 & 0.665 & 0.672 & 1436.40 & 30 & 0.125 \\
Est -1 & 4 & 0.644 & 0.646 & 1398.76 & 30 & 0.138 \\
Est- 2 & 5 & 0.744 & 0.746 & 2282.95 & 40 & 0.086 \\
Est-3 & 6 & 0.707 & 0.707 & 2318.96 & 50 & 0.103 \\
G6pd & 2 & 0.666 & 0.668 & 418.24 & 10 & 0.125 \\
Idh & 5 & 0.333 & 0.331 & 969.69 & 40 & 0.500 \\
Ldh & 3 & 0.464 & 0.525 & 599.48 & 20 & 0.288 \\
Pep-1 & 3 & 0.469 & 0.449 & 690.36 & 20 & 0.283 \\
Pep-2 & 4 & 0.444 & 0.451 & 956.37 & 30 & 0.313 \\
Pgm & 6 & 0.550 & 0.542 & 1991.00 & 50 & 0.204 \\
Phi & 4 & 0.388 & 0.336 & 866.01 & 30 & 0.394 \\
Mean & & 0.572 & 0.572 & & & 0.226 \\
\hline
\end{tabular}


separation as distinct species of T. baschierii (STR), T. apenninicus (VAL, TOS, FAT) and T. sujensis (SUJ), as formally assessed by Taiti \& Ferrara (1995) in their taxonomic review of cave woodlice of Tuscany.

The analysis of $\Theta$ - and $N m$-values shows a high degree of genetic subdivision in the studied groups, corresponding to low levels of gene flow. Mean $\mathrm{Nm}$-values for each group of populations are always $<1$ and pairwise comparisons within each single group show an $\mathrm{Nm}$-value close to $1(0.974)$ in only one case (VAL vs. TOS). This level of gene flow is near to the threshold of 1 indicated by Wright (1931) as the limit to maintain genetic homogeneity among populations; migration of individuals between the two populations could occur through the same system connecting the two caves. Indeed, troglophilic species are usually characterized by

Table $3 \Theta$ - and $\mathrm{Nm}$-values calculated for different geographical groups of Trichoniscus populations

\begin{tabular}{|c|c|c|}
\hline Group & $\Theta$ & $N m$ \\
\hline \multicolumn{3}{|c|}{ Apennine cave populations } \\
\hline VAL-TOS & 0.204 & 0.974 \\
\hline VAL-FAT & 0.419 & 0.346 \\
\hline TOS-FAT & 0.355 & 0.454 \\
\hline Mean & 0.326 & 0.591 \\
\hline \multicolumn{3}{|c|}{ Tuscan cave populations } \\
\hline STR-VAL & 0.894 & 0.026 \\
\hline STR-TOS & 0.783 & 0.069 \\
\hline STR-FAT & 0.859 & 0.041 \\
\hline Mean & 0.845 & 0.046 \\
\hline \multicolumn{3}{|c|}{ Epigean-hypogean populations } \\
\hline ELL-VAL & 0.699 & 0.107 \\
\hline ELL-TOS & 0.616 & 0.155 \\
\hline ELL-FAT & 0.667 & 0.124 \\
\hline ELL-STR & 0.490 & 0.260 \\
\hline Mean & 0.618 & 0.161 \\
\hline \multicolumn{3}{|c|}{ Insular populations } \\
\hline FRA-CAP & 0.778 & 0.071 \\
\hline FRA-ELB & 0.807 & 0.059 \\
\hline FRA-GOR & 0.647 & 0.136 \\
\hline CAP-ELB & 0.805 & 0.060 \\
\hline CAP-GOR & 0.732 & 0.091 \\
\hline ELB-GOR & 0.733 & 0.091 \\
\hline Mean & 0.750 & 0.084 \\
\hline \multicolumn{3}{|c|}{ Insular-continental populations } \\
\hline ELL-FRA & 0.657 & 0.130 \\
\hline ELL-CAP & 0.687 & 0.113 \\
\hline ELL-ELB & 0.529 & 0.222 \\
\hline ELL-GOR & 0.653 & 0.132 \\
\hline Mean & 0.631 & 0.149 \\
\hline
\end{tabular}

higher levels of gene flow among populations than troglobitic ones (Caccone, 1985), and in fact the most troglobitic population (STR) also shows the lowest values of gene flow.

Our results have revealed a certain degree of genetic differentiation even among the epigean populations belonging to the subspecies $T$. pusillus provisorius. Several studies have demonstrated the importance of dispersal as the main factor contributing to the genetic structure of natural populations (De Matthaeis et al., 1994, 1995). Many terrestrial isopods in general, and many Trichoniscidae in particular, are characterized by low vagility (Manicastri \& Taiti, 1994) and dispersal may occur only through ecologically suitable areas. Thus, local populations, not connected by gene flow, may undergo processes of genetic differentiation. Insular and cave populations can be treated as units subjected to the same evolutionary forces (bottlenecks, genetic drift, etc.) (Sbordoni et al., 1990). In our samples the level of genetic differentiation among continental and insular populations of $T$. pusillus provisorius (mean $D=0.6$ ) is of the same order of magnitude as that found between cave populations recognized as different species, e.g. $T$. baschierii and T. apenninicus. Hence, a specific status should be proposed even for these insular taxa. On the other hand, no data are yet available on the level of genetic differentiation among continental populations. Further investigations on a larger number of diploid and triploid continental populations, sampled from a wider area, are planned, in order to define the taxonomic status of these insular populations and to elucidate patterns of genetic relationships.

However, in order to analyse the genetic data from an evolutionary point of view, we have dated the beginning of independent evolution of the insular populations of $T$. pusillus provisorius from the epigean one using Nei's formula (1975) applied to the mean genetic distance calculated for ELL, FRA, ELB, GOR and CAP $(D=0.6)$. This approach, even if subject to large standard errors, has proved to be useful in dating cladogenetic allopatric events for populations distributed according to an insular model (Sbordoni et al., 1990), especially for genetic distances $<1$. The beginning of independent evolution of continental and insular populations should have started about 3 Myr ago; this dating agrees with the palaeogeographical events that affected Corsica and the Tuscan Archipelago, starting with the connection established during the Messinian salinity crisis, about $6 \mathrm{Myr}$ ago. This connection lasted until the beginning of the Pliocene, when a 
Fig. 4 A two-dimensional plot of populations of Trichoniscus resulting from correspondence analysis, based on 424 individual genotypes and 64 alleles at 15 common loci.

marine ingression split the non-Apennine part of Tuscany into a large archipelago, including the present Tuscan Archipelago (from 5 to 2 Myr ago) (Ambrosetti et al., 1979).

The triploid population (PUS) is genetically more related to ELL. According to Vandel (1960), $T$. pusillus provisorius is an expanding taxon, which found a refuge area in the Maritime Alps during Plio-Pleistocene glaciations and subsequently extended its range northward and southward when the climate again became favourable. The triploid form could have had a similar origin, after which it spread into central and northern Europe up to the highest latitudes known for these isopods, according to a pattern widely documented for several species of insects (Lokki, 1983).

In an analogous way it could be assumed that the Tuscan cave populations originated from an

Table 4 Variability estimates of Trichoniscus populations

\begin{tabular}{lcccc}
\hline Population & $\begin{array}{c}\text { Mean no. of } \\
\text { alleles per locus }(A)\end{array}$ & $\begin{array}{c}\text { Percentage of } \\
\text { polymorphic loci* }(P)\end{array}$ & $\begin{array}{c}\text { Mean heterozygosity } \\
\text { Direct count }\left(H_{\mathrm{o}}\right)\end{array}$ & $\begin{array}{c}\text { Mean heterozygosity } \\
\text { H-W expected }\left(H_{\mathrm{e}}\right) \S\end{array}$ \\
\hline MAT & 1.1 & 13.3 & 0.049 & 0.042 \\
STR & 1.5 & 40.0 & 0.027 & 0.067 \\
VAL & 1.6 & 40.0 & 0.050 & 0.047 \\
TOS & 1.4 & 33.3 & 0.116 & 0.108 \\
FAT & 1.1 & 6.7 & 0.056 & 0.034 \\
SUJ & 1.2 & 20.0 & 0.040 & 0.037 \\
PUS & 1.7 & 53.3 & 0.237 & 0.218 \\
ELL & 1.8 & 73.3 & 0.064 & 0.093 \\
FRA & 1.7 & 53.3 & 0.038 & 0.104 \\
CAP & 1.3 & 26.7 & 0.020 & 0.216 \\
ELB & 1.3 & 20.0 & 0.124 & \\
GOR & 1.6 & 60.0 & &
\end{tabular}

*A locus is considered polymorphic if the frequency of the most common allele does not exceed 0.99 .

$\S$ Unbiased estimate (see Nei, 1978).

(C) The Genetical Society of Great Britain, Heredity, 79, 463-472. 
Table 5 Values of the fixation index $(F)$ at all loci in the study populations, tested with a $\chi^{2}$-test for deviation from HardyWeinberg equilibrium

\begin{tabular}{|c|c|c|c|c|c|c|c|c|c|c|c|}
\hline & MAT & STR & VAL & TOS & FAT & SUJ & ELL & FRA & CAP & ELB & GOR \\
\hline Acph-I & & & & & & & $0.642 * * *$ & $0.591^{* * * *}$ & $0.795 * * *$ & & $0.634^{\text {**** }}$ \\
\hline Acph-2 & & & & & & & & & & & $0.766^{* * * *}$ \\
\hline Aph-I & -0.238 & & & & & -0.070 & $0.386^{* * * *}$ & -0.059 & $0.808^{* * *}$ & & $0.547^{* * * *}$ \\
\hline Aph-2 & & & & & & & $0.982^{* * *}$ & $0.733 * * *$ & $1.000^{* * * *}$ & & $0.547^{* * * * *}$ \\
\hline Est-1 & & -0.02 & & & & & $0.308 * * *$ & & & & $0.764^{* * * *}$ \\
\hline Est-2 & & & & & & & 0.948 米米 & $1.000^{* * *}$ & -0.243 & & $0.630^{\text {**** }}$ \\
\hline Est -3 & & -0.02 & -0.133 & -0.189 & & & & & & & \\
\hline G6pd & & -0.043 & & & & & -0.007 & & & & \\
\hline$I d h$ & & $1.000 * * *$ & -0.074 & -0.200 & $-0.714^{*}$ & -0.111 & $-1.051^{* * *}$ & -0.182 & & $0.675^{*}$ & -0.214 \\
\hline$L d h$ & & & & & & & -0.006 & & & $1.000 * * *$ & \\
\hline Pep-1 & & & -0.015 & & & & -0.005 & -0.08 & & & \\
\hline Рep-2 & & $0.475^{*}$ & -0.036 & $1.000^{* * *}$ & & & $0.624^{* * *}$ & 0.100 & & & -0.333 \\
\hline Pgm & -0.217 & $1.000^{* * * * *}$ & -0.023 & 0.05 & & & $1.000 * * *$ & & & & \\
\hline Phi & & & -0.088 & $-0.349 * * *$ & & & & -0.049 & & 0.440 & 0.190 \\
\hline
\end{tabular}

${ }^{*} P \leq 0.05,{ }^{* *} P \leq 0.01,{ }^{* * *} P \leq 0.005$.

ancestral form during the Plio-Pleistocene climate changes (average divergence time about $3 \mathrm{Myr}$ between the cave populations and the epigean ones). This evidence is also supported by gene flow levels among epigean/hypogean Tuscan populations (Table 3). Even if the mean $\mathrm{Nm}$ value (0.161) is low, it is still not zero, and it would thus seem that populations continue to exchange genes. On the other hand, similar gene flow levels have also been reported in cave beetles (Speonomus delarouzeei Fairmaire, 1861), for populations known to have evolved reproductive barriers (Caccone, 1985). It is likely that the present cave populations retain a certain amount of the ancestral gene pool and that the present pattern of genetic differentiation has been reached through bottlenecks followed by genetic drift (Barr, 1968). Thus, the level of gene flow found is the so-called 'historical pattern of gene exchange' (Larson et al., 1984; Gentile, 1994), which reflects connections that occurred in the past.

To test the validity of the previously discussed historical reconstruction, we performed a phylogenetic analysis by means of the distance Wagner procedure (Farris, 1972) with the MAT population selected as an outgroup (Fig. 3). The use of electrophoretic data to estimate phylogenies has been debated (Avise, 1994); even so, trees based on genetic distance/similarity matrices have often been used to recognize presumed phylogenetic relationships (Yang et al., 1974; Bullini, 1983). The possibility of using phylogenetic analysis in biogeographical studies is widely discussed in Forey et al. (1992); from this point of view our tree in Fig. 3 seems to support Vandel's hypothesis (1960) stated previously. PUS and ELL were found to be the most primitive populations, whereas the insular and cave populations, which join in two distinct groups, would be the most derived. SUJ is related to the primitive populations (PUS, ELL), which can be explained by the distribution of $T$. sujensis in the Ligurian Apennines, a mountain chain that extends to the Maritime Alps. It is likely that the actual cave $T$. sujensis populations would have stemmed from an ancestral epigean peripheral stock of populations during PlioPleistocene glaciations, as documented for other taxa (Sbordoni, 1982).

Genetic variability $\left(H_{\circ}\right)$ ranges from 0.020 (ELB) to 0.124 (GOR) in the diploid populations. In the cave populations, in particular, polymorphism levels are lower than those previously found in several cave taxa (Sbordoni, 1982), but are of the same order as the values found in other species of Oniscidea, both epigean and cavernicolous (Beck \& Price, 1981; Cobolli Sbordoni et al., 1995). Thus, the observed levels of enzyme polymorphism could simply reflect a particular taxon-dependent genetic pattern. Moreover, one possible explanation proposed by Beck \& Price (1981) to explain the observed heterozygote deficiency in woodlice populations is the existence of a nonrandom mating system (e.g. assortative mating) coupled with limited dispersal ability.

An estimate of intrapopulational variability in the triploid population PUS has been expressed as total clonal diversity, $\mathrm{TCD}=5.263$; a similar value has been obtained by Jaenike et al. (1982) on groups of 
parthenogenetic earthworms. Moreover, Theisen et al. (1995) found 15 genetically distinct clones of $T$. pusillus pusillus, correlated with various ecological gradients; these findings have been interpreted as a strategy to obtain optimal adaptations to heterogeneous environments.

In the PUS population we noticed the presence of a 'fixed heterozygote' pattern that could be explained as a gene duplication at some loci (Est-1, Est-3, Idh). It means that two variants of the same enzyme are present, which could lead to an extension of abiotic parameters under which normal development can take place. Thus, the multiplicity of enzymes provides a good hypothesis to account for the wider distribution of the triploid and tetraploid forms relative to diploid progenitors (Theisen et al., 1995).

\section{References}

AMBrosetTI, P., CARBONI, M. G., CONTI, M. A., COSTANTINI, A., ESU, D., GANDIN, A. ET AL. 1979. Evoluzione paleogeografica e tettonica nei bacini tosco-umbro-laziali nel Pliocene e nel Pleistocene inferiore. Mem. Soc. Geol. It., 19 [1978], 573-580.

ARGANO, R., BALDARI, F. AND MANICASTRI, C. 1978. Isopodi sotterranei italiani (Crustacea, Malacostraca). Lav. Soc. Ital. Biogeogr. (N.S.), 7, 119-137.

AVISE, J. C. 1994. Molecular Markers, Natural History and Evolution. Chapman and Hall, New York.

BARR, T. C., JR. 1968. Cave ecology and the evolution of troglobites. Evol. Biol., 2, 35-102.

BECK, M. L. AND PRICE, J. O. 1981. Genetic variation in the terrestrial isopod, Armadillidium vulgare. J. Hered., 72, 15-18.

Benzecri, J. P. 1973. L'Analyse des Données II. L'Analyse des Correspondances. Dunod, Paris.

вӧнмЕ, w. 1978. Kühnelt's principle of regional stenoecy and its bearing on the subspecies problem: a theoretical approach. Z. Zool. Syst. Evolforsch., 16, 256-266.

BULliNI, L. 1983. Taxonomic and evolutionary inferences from electrophoretic studies of various animal groups. In: Oxford, G. S. and Rollinson, D. (eds) Protein Polymorphism: Adaptive and Taxonomic Significance, pp. 179-192. Systematics Association Special Vol. 24. Academic Press, London.

CACCONE, A. 1985. Gene flow in cave arthropods: a qualitative and quantitative approach. Evolution, 39, 1223-1235.

COBOlll SBORDONI, M., DE MATTHAEIS, E., OMODEO, P., BIDOL1, R. AND RODINO, E. 1987. Allozyme variation and divergence between diploid and triploid populations of Allolobophora caliginosa (Lumbricidae: Oligochaeta). In: Bonvicini Pagliai, A. M. and Omodeo, P. (eds) On Earthworms, pp. 53-74. Selected Symposia and Monographs U.Z.I., vol. 2. Mucchi, Modena.
COBOlli SBORdoni, M., MATTOCCIA, M., LA ROSA, G., DE MATTHAEIS, E. AND SBORdONI, v. 1990. Secondary sympatric occurrence of sibling species of subterranean shrimps in the Karst. Int. J. Speleol., 19, 9-27.

COBOILl SBORDONI, M., TAITI, S., DE MATTHAEIS, E. AND KetMAIER, V. 1995. Genetic relationships among populations of the Oritoniscus paganus group (Crustacea, Isopoda, Oniscidea) from Corsica and Giannutri (Tuscan Archipelago). Mem. Biospéol., 22, 13-16.

Culver, D. C. 1982. Cave Life. Harvard University Press, Cambridge, MA.

de Matthaeis, E., Allegrucci, G., CACCONE, A., CesarONI, D., COBOlli SBORdoni, M. AND SBORdONI, v. 1983. Genetic differentiation between Penaeus kerathurus and P. japonicus (Crustacea, Decapoda). Mar. Ecol. Prog. Ser, 12, 191-197.

de matthaeis, E., Cobolli, M., Mattoccia, M., SaCCoCCIO, P. AND SCAPINI, F. 1994. Genetic divergence between natural populations of Mediterranean sandhoppers (Crustacea, Amphipoda). In: Beaumont, A. R. (ed.) Genetics and Evolution of Aquatic Organisms, pp. 15-29. Chapman and Hall, London.

dE matthaEis, E., COBOlli, M., mattoccia, M. AND SCAPINI, F. 1995. Geographic variation in Talitrus saltator (Crustacea, Amphipoda): biochemical evidence. Boll. Zool., 62, 77-84.

FARRIS, J. S. 1972. Estimating phylogenetic trees from distance matrices. Am. Nat., 106, 645-668.

FOREY, P. L., HUMPHRIES, C. J., KITCHING, I. L., SCOTLAND, R. W., Siebert, D. J. AND Williams, D. M. 1992. Cladistics. A Practical Course in Systematics. The Systematics Association Publications, Vol. 10. Oxford University Press, New York.

GENTILE G. 1994. Struttura genetica di popolazioni e variazione geografica nell'Isopode terrestre Androniscus dentiger dell'Italia Centrale (Isopoda, Oniscidea, Trichoniscidae). Ph.D. Thesis, University of Rome 'La Sapienza'.

GOUDET, J. 1995. FSTAT version 1.2: a computer program to calculate $F$-statistics. J. Hered., 86, 485-486.

HEDRICK, P. W. 1971. A new approach to measuring genetic similarity. Evolution, 25, 276-280.

JAENIKE, J., AUSUBEL, S. AND GRIMALDI, D. A. 1982. On the evolution of clonal diversity in parthenogenetic earthworms. Pedobiologia, 23, 304-310.

JONES, R., CULVER, C. D. AND KANE, T. C. 1992. Are parallel morphologies of cave organisms the result of similar selection pressures? Evolution, 46, 353-365.

LAING, C. D., CARMODY, G. R. AND PECK, S. B. 1976. How common are sibling species in cave-inhabiting invertebrates? Am. Nat., 110, 184-189.

LARSON, A., WAKE, D. B. AND YANEV, K. P. 1984. Measuring gene flow among populations having high levels of genetic fragmentation. Genetics, 106, 293-308.

LEVENE, H. 1949. On a matching problem arising in genetics. Am. Math. Stat., 20, 91-94.

LOKK1, J. 1983. Protein variation and the origin of parthenogenetic forms. In: Oxford, G. S. and Rollinson, 
D. (eds) Protein Polymorphism: Adaptive and Taxonomic Significance, pp. 223-238. Systematics Association Special Vol. 24. Academic Press, London.

MANICASTRI, C. AND TAITI, S. 1994. Gli Isopodi terrestri dell'Appennino umbro- marchigiano (Crustacea, Oniscidea). Biogeografia. Lavori della Società Italiana di Biogeografia (N.S.), 17 [1993], 125-150.

MAYR, E. 1975. Grundlagen der Zoologischen Systematik. Parey, Hamburg.

NEI, M. 1975. Molecular Population Genetics and Evolution. North Holland Press, Amsterdam.

NEl, M. 1978. Estimation of average heterozygosity and genetic distance from a small number of individuals. Genetics, 89, 583-590.

Rogers, J. S. 1972. Measures of Genetic Similarity and Genetic Distance. Stud. Gen. Soc. Austin, TX. 7213, $145-153$.

ROHLF, F. J. 1988. Ntsys-pc. Numerical Taxonomy and Multivariate Analysis System. Version 1.80. Applied Biostatistics, New York.

SBORDONI, v. 1982. Advances in speciation of cave animals. In: Barigozzi, C. (ed.) Mechanisms of Speciation, pp. 219-240. Alan R. Liss, New York.

SBORDONI, v., CACCONE, A., ALLEGRUCCI, G. AND CESARONI D. 1990. Molecular island biogeography. Atti Conv. Lincei, 85, 55-83.

SiMPSON, E. H. 1949. Measurement of diversity. Nature, 163, 688 .

SNEATH, P. H. A. AND SOKAL, R. R. 1973. Numerical Taxonomy. Freeman, San Francisco.

SWOFFORD, D. L. AND SELANDER, R. B. 1981. BIOSYS-1: a FORTRAN program for the comprehensive analysis of electrophoretic data in population genetics and systematics. J. Hered., 72, 281-283.

IAITI, S. AND FERRARA, F. 1995. Isopodi terrestri (Crustacea, Oniscidea) delle grotte della Toscana (Italia Centrale). Mem. Biospèol., 22, 169-196.

THEISEN, B. F., CHRISTENSEN, B. AND ARCTANDER, P. 1995. Origin of clonal diversity in triploid parthenogenetic Trichoniscus pusillus pusillus (Isopoda, Crustacea) based upon allozyme and nucleotide sequence data. J. Evol. Biol., 8, 71-80.

THORPE, J. P. 1983. Enzyme variation, genetic distance and evolutionary divergence in relation to levels of taxonomic separation. In: Oxford, G. S. and Rollinson, D. (eds) Protein Polymorphism: Adaptive and Taxonomic Significance, pp. 131-152. Systematics Association Special Vol. 24. Academic Press, London.

THORPE, R. S. 1987. Geographic variation: a synthesis of cause, data, pattern and congruence in relation to subspecies, multivariate analysis and phylogenesis. Boll. Zool., 54, 3-11.

VANDEL, A. 1960. Isopodes terrestres (Première partie)Faune de France, Vol. 64. Lechevalier, Paris.

WEIR, B. S. AND COCKERHAM, C. C. 1984. Estimating $F$-statistics for the analysis of population structure. Evolution, 38, 1358-1370.

WRIGHT s. 1931. Evolution in Mendelian populations. Genetics, 16, 97-159.

yang, S. y., SOUlé, M. AND gorman, G. C. 1974. Anolis lizards of the eastern Caribbean: a case study in evolution. I. Genetic relationships, phylogeny and colonization sequence of the roquet group. Syst. Zool., 23, 387-399. 